\title{
PERBANDINGAN HASIL BELAJAR MATEMATIKA SISWA ANTARA MODEL PEMBELAJARAN KOOPERATIF TIPE GROUP INVESTIGATION DAN STUDENT TEAMS ACHIE VEMENT DIVISION
}

\author{
${ }^{1}$ Maryani, ${ }^{2}$ M. Fachruddin S, ${ }^{3}$ Syafdi Maizora \\ 1,2,3 Prodi Pendidikan Matematika JPMIPA FKIP Universitas Bengkulu \\ Email :1'maryanimath18@gmail.com, ${ }^{2}$ mfachruddin.s@gmail.com, ${ }^{3}$ syafdiichiemaizora@unib.ac.id
}

\begin{abstract}
Abstrak
Penelitian ini bertujuan untuk melihat perbedaan hasil belajar matematika siswa antara model pembelajaran kooperatif tipe Group Investigation dan Student Teams Achievement Division pada bangun ruang sisi datar di SMP Negeri 4 Kota Bengkulu. Penelitian ini merupakan penelitian eksperimen semu dengan populasi siswa Kelas VIII SMP Negeri 4 Kota Bengkulu. Sampel diambil dengan teknik cluster sampling sehingga diperoleh kelas eksperimen (VIII ${ }_{4}$ ) dengan jumlah 35 siswa yang menerapkan model pembelajaraan kooperatif tipe Group Investigation dan kelas kontrol (VIII ${ }_{5}$ ) dengan jumlah 34 siswa yang menerapkan model pembelajaran kooperatif tipe Student Teams Achievement Division. Berdasarkan hasil analisis data manggunakan uji $\mathrm{t}$ diperoleh $\mathrm{t}_{\text {hitung }}=0,02$ dan $\mathrm{t}_{\text {tabel }}$ dengan taraaf nyata $\alpha=0,05, \mathrm{dk}=66$ diperoleh $\mathrm{t}_{\text {tabel }}=2,00$, sehingga $\mathrm{t}_{\text {hitung }}$ terletak antara $2,00_{1} \leq$ $\mathrm{t}_{\text {hitung }} \leq 2,00$ maka $\mathrm{H}_{0}$ diterima. Hal ini menunjukkan bahwa tidak terdapat perbedaan yang signifikan antara hasil belajar matematika siswa dengan model pembelajaran kooperatif tipe Group Investigation dan Student Teams Achievement Divisiondi Kelas VIII SMP Negeri 4 Kota Bengkulu.
\end{abstract}

Kata Kunci: hasil belajar, GI, dan STAD

\begin{abstract}
The purpose of this research is to find out the difference between the result of student learning which taught by cooperative learning Group Investigation type and Student Teams Achievement Division type on polyhedron in the class VIII of Junior High School 4 Bengkulu City. This research is quasy experiment research with population is the student in class VIII of Junior High School 4 Bengkulu City. The sample in this research is get from cluster sampling, so the experiment class (VIII 4 ) are 35 students by using Group Investigation an control class (VIII 5 ) are 34 students by using Student Teams Achievement Division. Based on data analysis by using $t$ test is get $t_{\text {count }}=0,02$ and $t_{\text {tabel }}$ with $\alpha=0,05$, $d f=66$ get $t_{\text {tabel }}=2,00$, so $t_{\text {count }}$ is placed between $-2,00 \leq t_{\text {count }} \leq 2,00$. This matter, $H_{0}$ accepted which means there is no significant differences between the result of student learning between cooperative learning Group Investigation type and Student Teams Achievement Division type in class VIII of Junior High School 4 Bengkulu City.
\end{abstract}

Keyword: result of student learning, GI, and STAD

\section{PENDAHULUAN}

Menurut Depdiknas (2006), salah satu tujuan pembelajaran matematika yakni memahami dan menerapkan (konsep, prosedur, prinsip, teorema, dan ide matematis), menjelaskan keterkaitan antar konsep dan mengaplikasikan konsep atau algoritma, secara luwes, akurat, efisien, dan tepat dalam pemecahan masalah, sehingga mata pelajaran matematika berguna untuk membekali peserta didik dengan kemampuan berpikir logis, analitis, sistematis, kritis, dan kreatif, serta kemampuan bekerjasama. Berkenaan dengan pencapaian tujuan pembelajaran matematika tersebut hendaknya semua pihak dan prasarana pendukung perlu diperhatikan. Fenomena yang seringkali terjadi yaitu proses pembelajaran umumnya berlangsung hanya berpusat pada guru dan siswa hanya menerima serta menghafal informasi yang diperolehnya, sehingga siswa hanya dibekali kemampuan untuk menghapal dan menerapkan yang dipelajari di sekolah secara prosedural tanpa pemahaman. 
Hasil wawancara pada tanggal 30 Januari 2017 terhadap salah satu guru mata pelajaran matematika di SMP Negeri 4 Kota Bengkulu, ditemukan bahwa proses pembelajaran menggunakan Kurikulum 2013 dengan pendekatan saintifik belum bisa diterapkan sepenuhnya. Keadaan ini dikarenakan siswa yang selama ini terbiasa dengan pembelajaran konvensional yang berpusat pada guru. Hal ini menyebabkan siswa kurang antusias dan aktif dalam pembelajaran, karena siswa hanya menunggu informasi yang disampaikan oleh guru sebagai pendidik.

Dalam meningkatkan makna pada proses pembelajaran, maka perlu diadakannya variasi model pembelajaran yang digunakan. Variasi ini diharapkan dapat membuat siswa menjadi lebih aktif, antusias, dan tertarik dengan proses pembelajaran yang berlangsung serta membiasakan siswa menemukan sendiri pengetahuannya. Salah satu model yang bisa digunakan adalah model pembelajaran kooperatif.

Pembelajaran kooperatif menurut Johnson, dkk (Wardoyo, 2013: 44), merupakan proses belajar mengajar yang melibatkan penggunaan kelompok-kelompok kecil yang memungkinkan siswa untuk bekerja secara bersama-sama di dalamnya dengan tujuan untuk memaksimalkan pembelajaran mereka sendiri dan pembelajaran satu sama lainnya. Model pembelajaran kooperatif memiliki banyak tipe, dua diantaranya adalah tipe Group Investigation dan Student Teams Achievement Division.

Group Investigation merupakan proses perencanaan pengaturan kelas yang umum dimana para siswa bekerja dalam kelompok kecil dengan menggunakan pertanyaan kooperatif, diskusi kelompok, serta perencanaan dan proyek kooperatif (Sharan dalam Slavin, 2005: 24). Dalam proses pembelajarannya, siswa di tuntut untuk memiliki keterampilan komunikasi dan proses kelompok yang baik. Hosnan (2014: 258) menyebutkan bahwa Group Investigation dapat digunakan untuk membimbing siswa agar mampu berpikir sistematis, kritis, analitik, berpartisipasi aktif dalam belajar dan berbudaya kreatif melalui kegiatan pemecahan masalah. Dalam proses belajar melalui grup investigasi, siswa akan belajar aktif dan memberi kesempatan kepada siswa untuk berpikir sendiri. Dengan jalan itulah siswa dapat menyadari potensi dirinya.

Student Teams Achievement Division merupakan salah satu pembelajaran kooperatif yang diterapkan untuk menghadapi kemampuan siswa yang heterogen. Menurut Arindawati (Hosnan, 2014: 246) pada model pembelajaran STAD, siswa diberi kesempatan untuk melakukan kolaborasi dan elaborasi dengan teman sebaya dalam bentuk diskusi kelompok untuk memecahkan suatu permasalahan. Dalam penelitian ini, model STAD yang digunakan menggunakan LKS yang menerapkan pendekatan saintifik pada proses bekerja dan belajarnya. Hal ini dikarenakan pada SMP Negeri 4 Kota Bengkulu telah menerapkan kurikulum 2013.

\section{METODE PENELITIAN}

\section{Jenis Penelitian}

Jenis penelitian yang akan dilaksanakan pada penelitian ini adalah penelitian quasi eksperimen. Menurut Sugiyono (2015: 77) quasi eksperimen adalah penelitian yang mempunyai kelompok kontrol, tetapi tidak dapat berfungsi sepenuhnya untuk mengontrol variabel-variabel luar yang mempengaruhi pelaksanaan eksperimen.

Pada kelas sampel pertama (kelas eksperimen) pembelajaran dilaksanakan dengan menggunakan model pembelajaran kooperatif tipe Group Investigation dan pada kelas sampel kedua (kelas kontrol) pembelajaran dilaksanakan dengan model pembelajaran kooperatif tipe STAD.

\section{Subjek Penelitian}

Subjek pada penelitian ini adalah seluruh siswa kelas VIII di SMP Negeri 4 Kota Bengkulu, yang selanjutnya di pilih dua kelas yang homogen untuk dijadikan sampel.

\section{Teknik Pengumpulan Data}

Data yang digunakan dalam penelitian ini untuk mengukur tingkat kemampuan pemahaman konsep matematika yaitu dengan menggunakan instrumen postes. Postesdiberikan untuk kelas eksperimen yang 
menerapkan model pembelajaran kooperatif tipe Group Investigation dan kelas kontrol yang menerapkan model pembelajaran kooperatif tipe STAD. Skor diberikan sesuai dengan tingkat pencapaian berdasarkan jawaban yang diberikan siswa dalam lembar jawaban setelah siswa mengerjakan soal.

Sebelum postes digunakan, terlebih dahulu dilakukan analisis item dengan uji validitas, reliabilitas, dan taraf kesukaran serta daya pembeda. Dengan hasil sebagai berikut:

Tabel 1 Hasil uji instrumen

\begin{tabular}{|c|c|c|c|c|c|}
\hline $\begin{array}{l}\text { No } \\
\text { Soal } \\
\end{array}$ & $\begin{array}{c}\text { Uji } \\
\text { Validitas }\end{array}$ & $\begin{array}{c}\text { Uji } \\
\text { Reabilitas }\end{array}$ & $\begin{array}{l}\text { Uji Taraf } \\
\text { Kesukaran }\end{array}$ & $\begin{array}{l}\text { Uji Daya } \\
\text { Pembeda }\end{array}$ & Keterangan \\
\hline 1 & Cukup & \multirow{4}{*}{ Sedang } & Sedang & Sedang & Digunakan \\
\hline 2 & $\begin{array}{l}\text { Sangat } \\
\text { Tinggi }\end{array}$ & & Sedang & Baik & Digunakan \\
\hline 3 & $\begin{array}{l}\text { Sangat } \\
\text { Tinggi }\end{array}$ & & Sedang & Sedang & Digunakan \\
\hline 4 & Tinggi & & Sedang & Sedang & Digunakan \\
\hline
\end{tabular}

Berdasarkan tabel di atas diperoleh bahwa keempat soal yang diujicobakan dapat digunakan sebagai postes, karena telah memenuhi kriteria penerimaan keempat uji yang dilakukaan.

\section{Teknik Analisis Data}

\subsection{Pengujian Persyaratan Analisis}

\subsubsection{Uji Normalitas}

Rumus yang digunakan:

$$
x^{2}=\sum \frac{\left(f_{0}-f_{h}\right)^{2}}{f_{h}}(\text { Sugiyono, 2012: 19) }
$$

\subsubsection{Uji Homogenitas}

Uji homogenitas menggunakan Uji Bartlett. Kriteria pengujian: Tolak $\mathrm{H}_{0}$ yang menyatakan varians skornya homogen jika $x^{2} \geq x_{(1-\alpha)(d k)}^{2}$ (Sudjana, 2005: 263).

\subsection{Berdistribusi Normal}

\subsubsection{Pengujian Hipotesis}

$H_{0}: \mu_{1}=\mu_{2}$ (Tidak terdapat perbedaan yang signifikan antara hasil belajar matematika siswa dengan model pembelajaran kooperatif tipe Group Investigation dan Student Teams Achievement Division di Kelas VIII SMP Negeri 4 Kota Bengkulu

$H_{1}: \mu_{1} \neq \mu_{2} \quad$ (Terdapat perbedaan yang signifikan antara hasil belajar matematika siswa dengan model pembelajaran kooperatif tipe Group Investigation dan
Student Teams Achievement Division di Kelas VIII SMP Negeri 4 Kota Bengkulu)

Pengujian hipotesis dilakukan dengan menggunakan uji-t. pengujian dilakukan dengan $\alpha=0,05$ dan derajat kebebasan $(\mathrm{dk})=$ $\left(\mathrm{n}_{1}+\mathrm{n}_{2}-2\right)$. Rumus uji-t yang digunakan adalah :

$$
t=\frac{\overline{x_{1}}-\overline{x_{2}}}{\sqrt{\frac{\left(n_{1}-1\right) s_{1}^{2}+\left(n_{2}-1\right) s_{2}^{2}}{n_{1}+n_{2}-2}\left(\frac{1}{n_{1}}+\frac{1}{n_{2}}\right)}}
$$

(Sugiyono, 2012: 138)

\section{HASIL DAN PEMBAHASAN}

\section{A. HASIL}

\section{Uji Normalitas}

Uji normalitas data dilakukan dengan uji chi square, adapun hipotesisnya sebagai berikut:

$\mathrm{H}_{0}$ : data berdistribusi normal

$\mathrm{H}_{1}$ : data tidak berdistribusi normal

Kriteria pengujiannya adalah terima $\mathrm{H}_{0}$ jika $x_{h i}^{2} \sim$ ung $\leq x_{\text {tabel }}^{2}$, dalam kondisi lain maka $\mathrm{H}_{0}$ di tolak. Adapun hasil perhitungan menggunakan uji chi square di sajikan pada tabel berikut:

Tabel 2 Hasil perhitungan dengan uji chi

\begin{tabular}{|c|c|c|c|}
\hline \multicolumn{4}{c|}{ square } \\
\hline Kelas & $x_{\text {hitung }}^{2}$ & $x_{\text {tabel }}^{2}$ & Keterangan \\
\hline Eksperimen & 10,71 & 11,070 & $\mathrm{H}_{0}$ diterima \\
\hline Kontrol & 4,67 & 11,070 & $\mathrm{H}_{0}$ diterima \\
\hline
\end{tabular}

Dari tabel di atas, dapat dilihat bahwa pada kelas eksperimen hasil $x_{\text {hitung }}^{2}=10,71 \leq$ $x_{\text {tabel }}^{2}=11,070$, sehingga $\mathrm{H}_{0}$ diterima. Jadi, data pada kelas eksperimen berdistribusi normal.

Pada kelas kontrol hasil $x_{\text {hitung }}^{2}=4,67 \leq$ $x_{\text {tabel }}^{2}=11,070$, sehingga $\mathrm{H}_{0}$ diterima. Jadi, data pada kelas kontrol berdistribusi normal.

\section{Uji Homogenitas}

Uji homogenitas dilakukan dengan Uji Bartlett, adapun hipotesisnya sebagai berikut:

$$
\begin{aligned}
& \mathrm{H}_{0}: \sigma_{1}^{2}=\sigma_{2}^{2} \text { (data homogen) } \\
& \mathrm{H}_{1}: \sigma_{1}^{2} \neq \sigma_{2}^{2} \text { (data tidak homogen) }
\end{aligned}
$$

Kriteria pengujiannnya adalah terima $\mathrm{H}_{0}$ jika $x_{\text {hitung }}^{2} \leq x_{\text {tabel }}^{2}$, dalam kondisi yang lain maka $\mathrm{H}_{0}$ ditolak. Adapun hasil perhitungan 
menggunakan uji Bartlett di sajikan pada tabel berikut:

Tabel 3 Hasil perhitungan dengan uji Bartlett

\begin{tabular}{|c|c|l|}
\hline$x_{\text {hitung }}^{2}$ & $x_{\text {tabel }}^{2}$ & Keterangan \\
\hline 0,25 & 3,481 & $\mathrm{H}_{0}$ diterima \\
\hline
\end{tabular}

Dari tabel di atas, dapat dilihat bahwa hasil perhitungan dengan uji Bartlett adalah $x_{\text {hitung }}^{2}=0,25 \leq x_{\text {tabel }}^{2}=3,481$, sehingga $\mathrm{H}_{0}$ diterima. Jadi, data pada kedua sampel homogen yang berarti bahwa nilai varians pada kedua kelas tersebut tidak jauh berbeda.

\section{a. Hasil Pengujian Hipotesis}

Karena data berdistribusi normal dan homogen, maka pengujian hipotesis dilakukan dengan menggunakan uji $t$ untuk sampel independen. Adapun hipotesis yang akan di uji adalah sebagai berikut:

$H_{0}: \mu_{1}=\mu_{2}$ (Tidak terdapat perbedaan yang signifikan antara hasil belajar matematika siswa dengan model pembelajaran kooperatif tipe Group Investigation dan Student Teams Achievement Division di Kelas VIII SMP Negeri 4 Kota Bengkulu)

$H_{1}: \mu_{1} \neq \mu_{2} \quad$ (Terdapat perbedaan yang signifikan antara hasil belajar matematika siswa dengan model pembelajaran kooperatif tipe Group Investigation dan Student Teams Achievement Division di Kelas VIII SMP Negeri 4 Kota Bengkulu)

Kriteria pengujian hipotesis adalah jika nilai $-t_{\alpha / 2} \leq \mathrm{t}_{\text {hitung }} \leq t_{\alpha / 2}$ maka $\mathrm{H}_{0}$ diterima. Dan sebaliknya, jika $-t_{\alpha / 2}<t_{\text {hitung }}$ atau $t_{\text {hitung }}>t_{\alpha / 2}$ maka $\mathrm{H}_{0}$ ditolak. Adapun hasil perhitungan dengan uji $t$ untuk sampel independen disajikan pada tabel berikut:

\section{Tabel 4 Hasil perhitungan dengan uji $\boldsymbol{t}$}

\begin{tabular}{|c|c|l|}
\hline$t_{\text {hitung }}$ & $t_{\text {tabel }}$ & Keterangan \\
\hline 0,20 & 2,00 & $\mathrm{H}_{0}$ diterima \\
\hline
\end{tabular}

Dari tabel di atas dapat dilihat bahwa hasil perhitungan dengan uji $\mathrm{t}$ untuk sampel independen $t_{\text {hitung }}=0,20 \leq t_{\text {tabel }}=2,00$, sehingga $\mathrm{H}_{0}$ diterima. Jadi dapat disimpulkan bahwa tidak terdapat perbedaan yang signifikan antara hasil belajar matematika siswa dengan model pembelajaran kooperatif tipe Group Investigation dan Student Teams Achievement Division di Kelas VIII SMP Negeri 4 Kota Bengkulu.

\section{B. PEMBAHASAN \\ B.1 Analisis Hasil Belajar Siswa}

Hasil analisis data menunjukkan bahwa tidak terdapat perbedaan yang signifikan antara hasil belajar matematika siswa dengan model pembelajaran kooperatif tipe Group Investigation dan Student Teams Achievement Division. Hal ini disebabkan karena kedua kelompok sampel tersebut memiliki kemampuan yang sama pada materi Bidang Datar kedua kelompok sampel tersebut memiliki kemampuan yang sama pada materi Bidang Datar. Keterangan tersebut diperoleh dari hasil pretes yang telah dilakukan sebelumnya dengan materi tes tentang Bidang Datar, yang mana materi tersebut merupakan materi prasyarat untuk memahami materi bangun Ruang Sisi Datar. Selain itu, kedua kelompok subjek penelitian (Kelas $\mathrm{VIII}_{4}$ dan $\mathrm{VIII}_{5}$ ) telah dibentuk dari kelas yang homogen.

Hasil analisis data menunjukkan bahwa model pembelajaran kooperatif tipe Group Investigation dapat meningkatkan hasil belajar matematika siswa. Hal ini disebabkan karena terdapat fase-fase model Group Investigation yang memfasilitasi siswa untuk dapat meningkatkan hasil belajar siswa. Pada fase terbuka, yakni melaksanakan investigasi, peneliti membimbing siswa melalui pertanyaan-pertanyaan pada LKS (Lembar Kerja Siswa) yang mengarahkan siswa untuk mencari informasi dan melakukan investigasi untuk menemukan suatu konsep.

Selanjutnya, siswa dapat menggunakan informasi dan hasil investigasi tersebut untuk menemukan suatu konsep. Pada fase tersebut peneliti hanya memberikan bimbingan seperlunya, sehingga siswa-lah yang berperan besar dalam membangun sendiri pemahamannya.

Selain fase di atas, terdapat fase lain yang juga dapat meningkatkan pemahaman siswa, yakni Fase Penutup dan Penerapan, terdapat kegiatan dimana masing-masing kelompok 
mempresentasikan laporan akhir hasil investigasi yang telah mereka lakukan. Kegiatan tersebut membuat siswa dapat saling berbagi dan saling melengkapi informasi antar kelompok, karena hasil investigasi masingmasing kelompok belum tentu sama. Kedua fase tersebut yang dapat meningkatkan pemahaman siswa dengan model pembelajaran kooperatif tipe Group Investigation. Hasil analisis ini juga didukung oleh beberapa penelitian sebelumnya, diantaranya penelitian dari Juventy (2014), Zuhandra (2016) dan Areka (2013).

Pada kelas kontrol, hasil analisis data menunjukkan bahwa model pembelajaran kooperatif tipe Student Teams Achievement Division, dapat meningkatkan hasil belajar matematika siswa. Hal ini sesuai dengan hasil penelitian Sugiyarti (2015) yang menunjukkan bahwa model pembelajaran tersebut dapat meningkatkan hasil belajar siswa. Hal ini disebabkan karena terdapat fase-fase model Student Teams Achievement Division yang memfasilitasi siswa untuk dapat menemukan kembali konsep bangun ruang. Pada fase 4 , yaitu membimbing kelompok bekerja dan belajar (kerja tim), siswa diberikan LKS (Lembar Kerja Siswa) sebagai latihan untuk dapat menemukan kembali konsep bangun ruang setelah pemaparan materi yang dilakukan oleh guru dan pengaplikasiannya pada soal latihan yang terdapat pada LKS.

Selain fase di atas, terdapat fase lain yang juga dapat meningkatkan pemahaman siswa terhadap suatu konsep yang telah dipelajari, yakni fase 5. Pada fase 5 atau evaluasi, terdapat kegiatan dimana salah satu kelompok mempresentasikan hasil kerja kelompoknya dan kelompok lain mendengarkan serta menanggapi hasil presentasi tersebut. Selanjutnya, dilakukan juga evaluasi berupa pengerjaan kuis secara individu dan kegiatan ini dilaksanakan di setiap pertemuan. Kegiatan tersebut membuat siswa terlatih untuk mengerjakan soal atau menyelesaikan masalah bangun ruang. Kedua fase tersebut yang dapat meningkatkan pemahaman dan hasil belajar siswa.

\section{B.2 Perbandingan Hasil Belajar Matematika Siswa dengan Model Pembelajaran Kooperatif tipe Group Investigation dan Student Teams Achievement Division dengan Pendekatan Saintifik}

Berdasarkan hasil perhitungan uji hipotesis dengan uji $\mathrm{t}$ untuk sampel independen $t_{\text {hitung }}=$ $0,20 \leq t_{\text {tabel }}=2,00$, maka $\mathrm{H}_{0}$ diterima. Hal ini menunjukkan bahwa tidak terdapat perbedaan yang signifikan antara hasil belajar matematika siswa dengan model pembelajaran kooperatif tipe Group Investigation dan Student Teams Achievement Division. Kesimpulan ini bertentangan dengan penelitian yang dilakukan oleh Fitriana (2011) yang menunjukkan bahwa prestasi belajar matematika siswa dengan model pembelajaran kooperatif tipe Group Investigation lebih baik daripada dengan tipe Student Teams Achievement Division.

Hal ini diperkirakan karena kegiatan kelompok pada model STAD yang dilakukan oleh kelompok pada fase 4 bukan hanya mengerjakan latihan soal. Disini kegiatan kelompok difasilitasi dengan LKS yang menuntut siswa menemukan kembali konsep yang telah dipaparkan oleh guru, selanjutnya mereka mengerjakan soal latihan yang juga terdapat pada LKS. Selain itu, hal tersebut juga disebabkan karena sumber masalah yang disajikan pada kedua LKS berasal dari sumber ilmu atau informasi bangun ruang yang sama.

\section{SIMPULAN DAN SARAN}

\section{A. Simpulan}

Berdasarkan hasil penelitian yang telah dilakukan dapat disimpulkan bahwa tidak terdapat perbedaan yang signifikan antara hasil belajar matematika siswa dengan model pembelajaran kooperatif tipe Group Investigation dan Student Teams Achievement Division di Kelas VIII SMP Negeri 4 Kota Bengkulu. Ini ditunjukkan dari hasil perhitungan uji hipotesis dengan uji $\mathrm{t}$ untuk sampel independen $t_{\text {hitung }}=0,20 \leq t_{\text {tabel }}=$ 2,00, maka $\mathrm{H}_{0}$ diterima.

\section{B. Saran}


Saran yang dapat peneliti kemukakan berdasarkan penelitian yang telah dilakukan:

1. Pada awal penelitian ditemukan masalah kekurangan waktu pembelajaran di kedua kelas akibat ada kelompok yang terlalu lama menyelesaikan LKS. Hal ini bisa diatasi dengan cara membagi perhatian dan memberikan bimbingan kepada kelompok yang mengalami kesulitan dalam menyelesaikan LKS tersebut.

2. Pembagian anggota kelompok bisa dilakukan dengan cara mengelompokkan siswa yang memiliki kemampuan tinggi dengan siswa yang berkemampuan rendah.

\section{DAFTAR PUSTAKA}

Areka, Meidy Putra. 2013. Meningkatkan Aktivitas dan Hasil Belajar Matematika Siswa dengan Menerapkan Model Pembelajaran Kooperatif Learning Tipe Group Investigation pada Pokok Bahasan Bangun Ruang di SMP Negeri 5 Kota Bengkulu. Skripsi tidak diterbitkan. Bengkulu: Universitas Bengkulu

Eggen dan Kauchak.2012.Strategi dan Model Pembelajaran. Terjemahan oleh Satrio Wahono. Jakarta: PT Indeks

Fitriana, Laila. 2011. "Pengaruh Model Pembelajaran Cooperative Tipe Group Investigation (GI) Dan STAD Terhadap Prestasi Belajar Matematika Ditinjau Dari Kemandirian Belajar Siswa". Jurnal dalam Seminar Nasional Matematika dan Pendidikan Matematika ISBN 978-979-16353-6-3. Hal 1

Hosnan. 2014. Pendekatan Saintifik dan Kontekstual Dalam Pembelajaran Abad 21. Ghalia Indonesia.Bogor

Junvefty. $2014 \quad$ Penerapan Model Pembelajaran Kooperatif Tipe Student Teams Achievement Division (STAD) pada Siswa Kelas VIII SMP Negeri 8 Bengkulu. Skripsi tidak diterbitkan. Bengkulu: Universitas Bengkulu
Slavin, Robert E. 2005. Cooperative Learning Teori, Riset dan Praktik. Terjemahan oleh Narulita Yusron. Tanpa tahun. Bandung: Nusa Media

Sudjana. 2005. Metoda Statistika. Bandung: Tarsito

Sugiyarti. 2015. Perbandingan Hasil Belajar Matematika Siswa antara Model Pembelajaran Generatif (Generative Learning) denangan Model Pembelajaran Kooperatif Tipe Student Teams Achievement Division (STAD) di Kelas VIII SMP N 1 Pondok Kelapa. Skripsi tidak diterbitkan. Bengkulu: Universitas Bengkulu

Sugiyono. 2012. Statistik untuk Penelitian. Bandung: CV Alfabeta

Wardoyo, Sigit Mangun. Pembelajaran Konstruktivisme. 2013. Purbalingga: Alfabeta

Zuhandra, Veri Oktavius. 2016. Penerapan Model Pembelajaran Kooperatif Tipe Group Investigation untuk Meningkatkan Hasil Belajar Matematika Siswa di SMP Negeri 11 Kota Bengkulu Tahun Ajaran 2015/2016. Skripsi tidak diterbitkan. Bengkulu: Universitas Bengkulu 